\title{
The History of Nanoscience and Nanotechnology: From Chemical-Physical Applications to Nanomedicine
}

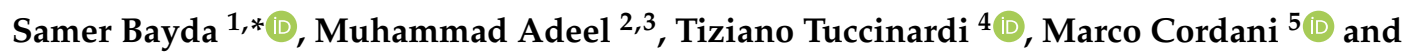 \\ Flavio Rizzolio $2,6, *$ (D) \\ 1 Department of Chemistry, Faculty of Sciences, Jinan University, Tripoli 818, Lebanon \\ 2 Pathology Unit, Centro di Riferimento Oncologico di Aviano (CRO) IRCCS, 33081 Aviano, Italy; \\ muhammad.adeel@unive.it \\ 3 PhD School in Science and Technology of Bio and Nanomaterials, University Ca' Foscari of Venice, \\ 30170 Venice, Italy \\ 4 Department of Pharmacy, University of Pisa, 56126 Pisa, Italy; tiziano.tuccinardi@farm.unipi.it \\ 5 Instituto Madrileño de Estudios Avanzados en Nanociencia (IMDEA Nanociencia), 28049 Madrid, Spain; \\ marco.cordani@imdea.org \\ 6 Department of Molecular science and Nanosystems, University Ca' Foscari of Venice, 30170 Venice, Italy \\ * Correspondence: samer.bayda@jinan.edu.lb (S.B.); flavio.rizzolio@unive.it (F.R.); Tel.: +961-06-447 \\ 907 (S.B.); +39-0434-659026 (F.R.)
}

Academic Editor: Alejandro Baeza

Received: 7 November 2019; Accepted: 20 December 2019; Published: 27 December 2019

\begin{abstract}
Nanoscience breakthroughs in almost every field of science and nanotechnologies make life easier in this era. Nanoscience and nanotechnology represent an expanding research area, which involves structures, devices, and systems with novel properties and functions due to the arrangement of their atoms on the $1-100 \mathrm{~nm}$ scale. The field was subject to a growing public awareness and controversy in the early 2000s, and in turn, the beginnings of commercial applications of nanotechnology. Nanotechnologies contribute to almost every field of science, including physics, materials science, chemistry, biology, computer science, and engineering. Notably, in recent years nanotechnologies have been applied to human health with promising results, especially in the field of cancer treatment. To understand the nature of nanotechnology, it is helpful to review the timeline of discoveries that brought us to the current understanding of this science. This review illustrates the progress and main principles of nanoscience and nanotechnology and represents the pre-modern as well as modern timeline era of discoveries and milestones in these fields.
\end{abstract}

Keywords: nanoscience; nanotechnology; nanomaterials; nanoparticles; nanomedicine

\section{Definition of Nanoscience and Nanotechnology}

The prefix 'nano' is referred to a Greek prefix meaning 'dwarf' or something very small and depicts one thousand millionth of a meter $\left(10^{-9} \mathrm{~m}\right)$. We should distinguish between nanoscience, and nanotechnology. Nanoscience is the study of structures and molecules on the scales of nanometers ranging between 1 and $100 \mathrm{~nm}$, and the technology that utilizes it in practical applications such as devices etc. is called nanotechnology [1]. As a comparison, one must realize that a single human hair is $60,000 \mathrm{~nm}$ thickness and the DNA double helix has a radius of $1 \mathrm{~nm}$ (Figure 1) [2]. The development of nanoscience can be traced to the time of the Greeks and Democritus in the 5th century B.C., when scientists considered the question of whether matter is continuous, and thus infinitely divisible into smaller pieces, or composed of small, indivisible and indestructible particles, which scientists now call atoms. 


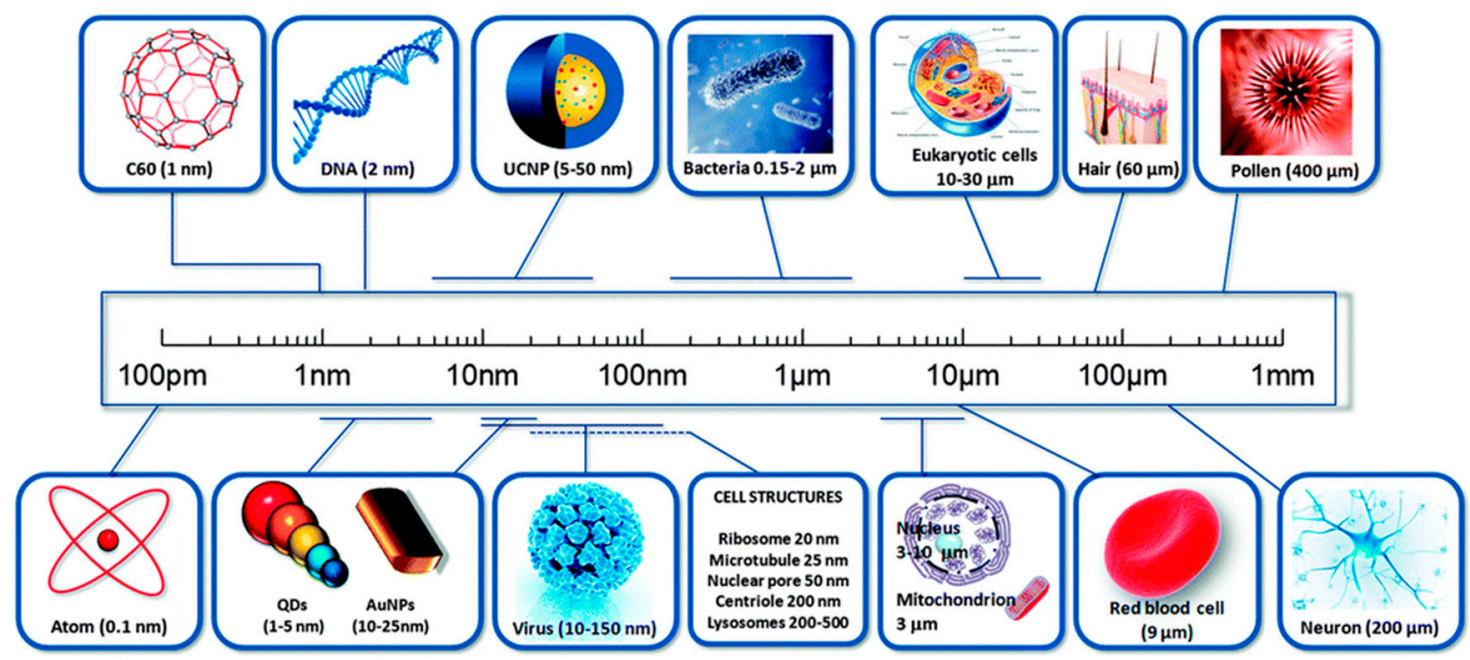

Figure 1. A comparison of sizes of nanomaterial. Reproduced with permission from reference [2].

Nanotechnology is one of the most promising technologies of the 21st century. It is the ability to convert the nanoscience theory to useful applications by observing, measuring, manipulating, assembling, controlling and manufacturing matter at the nanometer scale. The National Nanotechnology Initiative (NNI) in the United States define Nanotechnology as "a science, engineering, and technology conducted at the nanoscale ( 1 to $100 \mathrm{~nm}$ ), where unique phenomena enable novel applications in a wide range of fields, from chemistry, physics and biology, to medicine, engineering and electronics" [3]. This definition suggests the presence of two conditions for nanotechnology. The first is an issue of scale: nanotechnology is concerned to use structures by controlling their shape and size at nanometer scale. The second issue has to do with novelty: nanotechnology must deal with small things in a way that takes advantage of some properties because of the nanoscale [4].

We should distinguish between nanoscience and nanotechnology. Nanoscience is a convergence of physics, materials science and biology, which deal with manipulation of materials at atomic and molecular scales; while nanotechnology is the ability to observe measure, manipulate, assemble, control, and manufacture matter at the nanometer scale. There are some reports available, which provided the history of nanoscience and technology, but no report is available which summarize the nanoscience and technology from the beginning to that era with progressive events. Therefore, it is of the utmost requirements to summarize main events in nanoscience and technology to completely understand their development in this field.

\section{The Imaginative Pioneers of Nanotechnology}

The American physicist and Nobel Prize laureate Richard Feynman introduce the concept of nanotechnology in 1959. During the annual meeting of the American Physical Society, Feynman presented a lecture entitled "There's Plenty of Room at the Bottom" at the California Institute of Technology (Caltech). In this lecture, Feynman made the hypothesis "Why can't we write the entire 24 volumes of the Encyclopedia Britannica on the head of a pin?", and described a vision of using machines to construct smaller machines and down to the molecular level [5]. This new idea demonstrated that Feynman's hypotheses have been proven correct, and for these reasons, he is considered the father of modern nanotechnology. After fifteen years, Norio Taniguchi, a Japanese scientist was the first to use and define the term "nanotechnology" in 1974 as: "nanotechnology mainly consists of the processing of separation, consolidation, and deformation of materials by one atom or one molecule" [6].

After Feynman had discovered this new field of research catching the interest of many scientists, two approaches have been developed describing the different possibilities for the synthesis of nanostructures. These manufacturing approaches fall under two categories: top-down and bottom-up, which differ in degrees of quality, speed and cost. 
The top-down approach is essentially the breaking down of bulk material to get nano-sized particles. This can be achieved by using advanced techniques such as precision engineering and lithography which have been developed and optimized by industry during recent decades. Precision engineering supports the majority of the micro-electronics industry during the entire production process, and the high performance can be achieved through the use of a combination of improvements. These include the use of advanced nanostructure based on diamond or cubic boron nitride and sensors for size control, combined with numerical control and advanced servo-drive technologies. Lithography involves the patterning of a surface through exposure to light, ions or electrons, and the deposition of material on to that surface to produce the desired material [7].

The bottom-up approach refers to the build-up of nanostructures from the bottom: atom-by-atom or molecule-by-molecule by physical and chemical methods which are in a nanoscale range (1 nm to $100 \mathrm{~nm}$ ) using controlled manipulation of self-assembly of atoms and molecules. Chemical synthesis is a method of producing rough materials which can be used either directly in product in their bulk disordered form, or as the building blocks of more advanced ordered materials. Self-assembly is a bottom-up approach in which atoms or molecules organize themselves into ordered nanostructures by chemical-physical interactions between them. Positional assembly is the only technique in which single atoms, molecules or cluster can be positioned freely one-by-one [7].

The general concept of top down and bottom up and different methods adopted to synthesized nanoparticles by using these techniques are summarized in Figure 2. In 1986, K. Eric Drexler published the first book on nanotechnology "Engines of Creation: The Coming Era of Nanotechnology", which led to the theory of "molecular engineering" becoming more popular [8]. Drexler described the build-up of complex machines from individual atoms, which can independently manipulate molecules and atoms and thereby produces self-assembly nanotructures. Later on, in 1991, Drexler, Peterson and Pergamit published another book entitled "Unbounding the Future: the Nanotechnology Revolution" in which they use the terms "nanobots" or "assemblers" for nano processes in medicine applications and then the famous term "nanomedicine" was used for the first time after that [9].

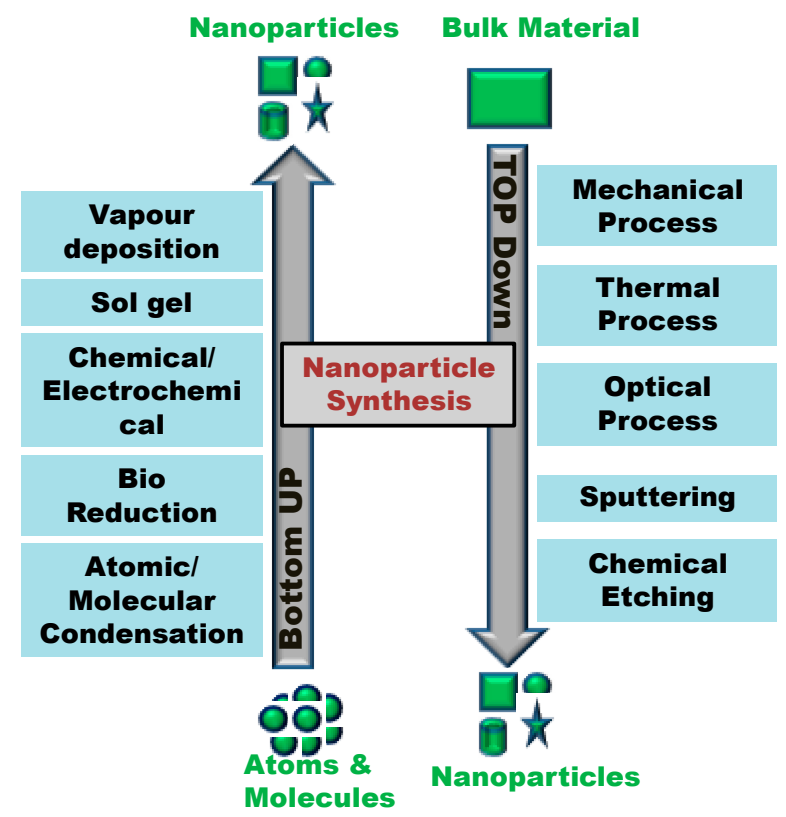

Figure 2. The concept of top down and bottom up technology: different methods for nanoparticle synthesis.

\section{History of Nanotechnology}

Nanoparticles and structures have been used by humans in fourth century AD, by the Roman, which demonstrated one of the most interesting examples of nanotechnology in the ancient world. 
The Lycurgus cup, from the British Museum collection, represents one of the most outstanding achievements in ancient glass industry. It is the oldest famous example of dichroic glass. Dichroic glass describes two different types of glass, which change color in certain lighting conditions. This means that the Cup have two different colors: the glass appears green in direct light, and red-purple when light shines through the glass (Figure 3) [10].

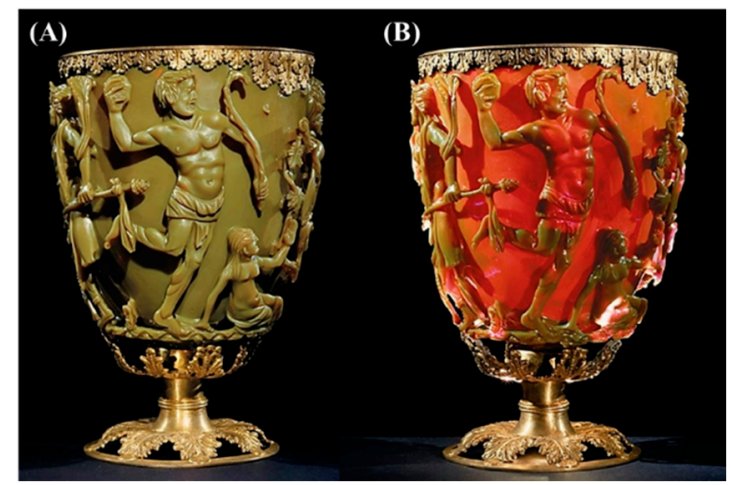

Figure 3. The Lycurgus cup. The glass appears green in reflected light (A) and red-purple in transmitted light (B). Reproduced with permission from reference [10].

In 1990, the scientists analyzed the cup using a transmission electron microscopy (TEM) to explain the phenomenon of dichroism [11]. The observed dichroism (two colors) is due to the presence of nanoparticles with 50-100 nm in diameter. X-ray analysis showed that these nanoparticles are silver-gold (Ag-Au) alloy, with a ratio of Ag:Au of about 7:3, containing in addition about $10 \%$ copper $(\mathrm{Cu})$ dispersed in a glass matrix [12,13]. The Au nanoparticles produce a red color as result of light absorption ( $\sim 520 \mathrm{~nm})$. The red-purple color is due to the absorption by the bigger particles while the green color is attributed to the light scattering by colloidal dispersions of Ag nanoparticles with a size $>40 \mathrm{~nm}$. The Lycurgus cup is recognized as one of the oldest synthetic nanomaterials [1]. A similar effect is seen in late medieval church windows, shining a luminous red and yellow colors due to the fusion of $\mathrm{Au}$ and $\mathrm{Ag}$ nanoparticles into the glass. Figure 4 shows an example of the effect of these nanoparticles with different sizes to the stained glass windows [14].

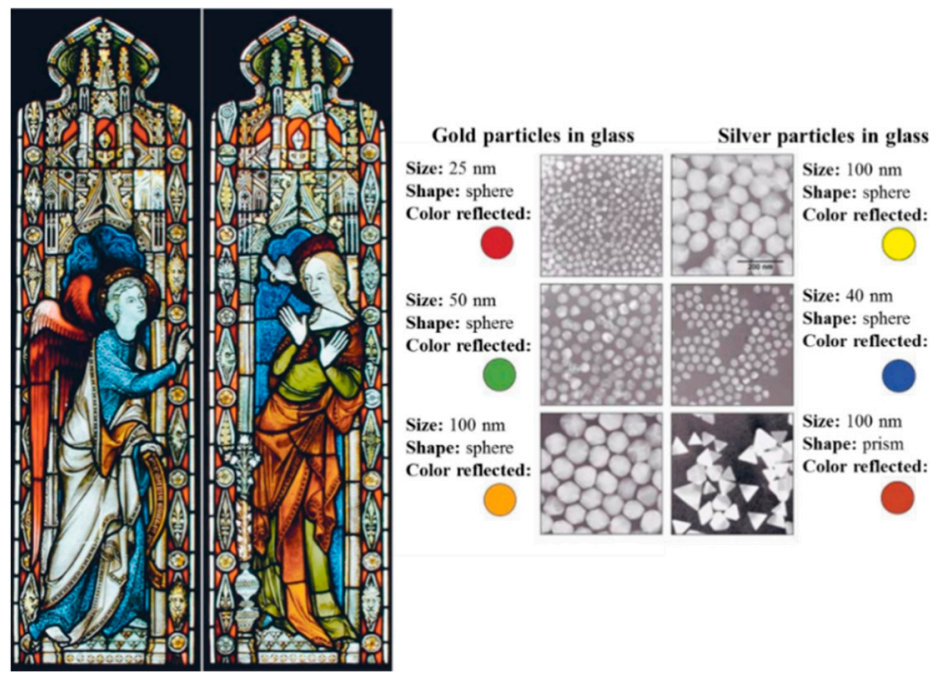

Figure 4. Effect of nanoparticles on the colors of the stained glass windows. Reproduced with permission from reference [14].

During the 9th-17th centuries, glowing, glittering "luster" ceramic glazes used in the Islamic world, and later in Europe contained Ag or copper $(\mathrm{Cu})$ or other nanoparticles [15]. The Italians 
also employed nanoparticles in creating Renaissance pottery during 16th century [16]. They were influenced by Ottoman techniques: during the 13th-18th centuries, to produce "Damascus" saber blades, cementite nanowires and carbon nanotubes were used to provide strength, resilience, and the ability to hold a keen edge [17]. These colors and material properties were produced intentionally for hundreds of years. Medieval artists and forgers, however, did not know the cause of these surprising effects.

In 1857, Michael Faraday studied the preparation and properties of colloidal suspensions of "Ruby" gold. Their unique optical and electronic properties make them some of the most interesting nanoparticles. Faraday demonstrated how gold nanoparticles produce different-colored solutions under certain lighting conditions [18]. The progression in nanotechnology due to the blessings of nanoscience are summarized in the Figure 5.

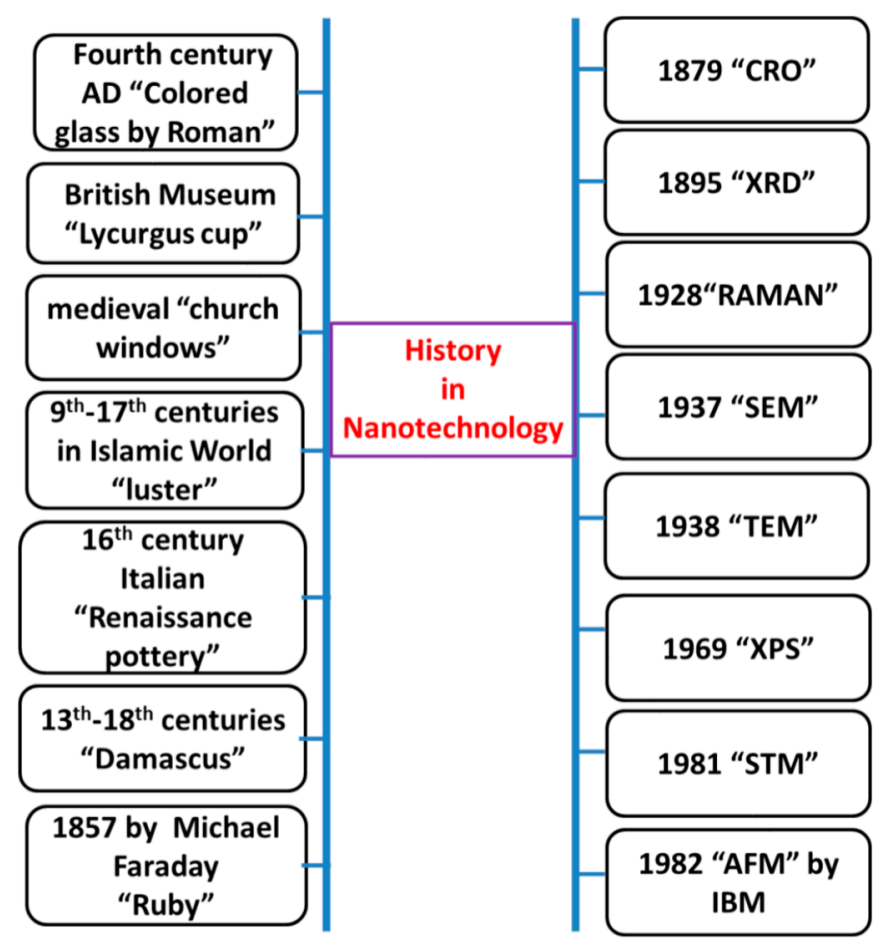

Figure 5. Progresses in Nanotechnology.

\section{Modern Era of Nanotechnology}

There was a progress in nanotechnology since the early ideas of Feynman until 1981 when the physicists Gerd Binnig and Heinrich Rohrer invented a new type of microscope at IBM Zurich Research Laboratory, the Scanning Tunneling Microscope (STM) [19,20]. The STM uses a sharp tip that moves so close to a conductive surface that the electron wave functions of the atoms in the tip overlap with the surface atom wave functions. When a voltage is applied, electrons "tunnel" through the vacuum gap from the atom of the tip into the surface (or vice versa). In 1983, the group published the first STM image of the $\mathrm{Si}(111)-7 \times 7$ reconstructed surface, which nowadays can be routinely imaged as shown in Figure $6[21,22]$. 


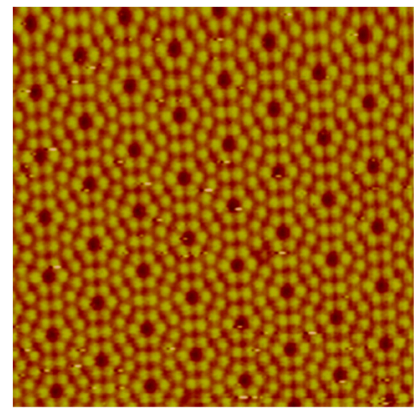

Figure 6. STM image of the $\mathrm{Si}(111)-7 \times 7$ reconstructed surface showing atomic scale resolution of the top-most layer of silicon atoms. Reproduced with permission from reference [22].

A few years later, in 1990, Don Eigler of IBM in Almaden and his colleagues used a STM to manipulate 35 individual xenon atoms on a nickel surface and formed the letters of IBM logo (Figure 7) [23]. The STM was invented to image surfaces at the atomic scale and has been used as a tool with which atoms and molecules can be manipulated to create structures. The tunneling current can be used to selectively break or induce chemical bonds.
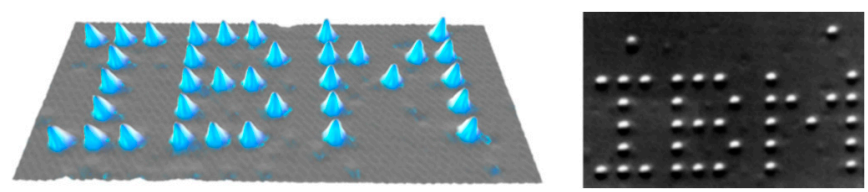

Figure 7. 35 Xenon atoms positioned on a nickel (110) substrate using a STM to form IBM logo. Reproduced with permission from reference [23].

In 1986, Binnig and Rohrer received the Nobel Prize in Physics "for their design of the STM". This invention led to the development of the atomic force microscope (AFM) and scanning probe microscopes (SPM), which are the instruments of choice for nanotechnology researchers today [24,25]. At the same time, in 1985, Robert Curl, Harold Kroto, and Richard Smalley discovered that carbon can also exist in the form of very stable spheres, the fullerenes or buckyballs [26]. The carbon balls with chemical formula $\mathrm{C} 60$ or C70 are formed when graphite is evaporated in an inert atmosphere. A new carbon chemistry has been now developed, and it is possible to enclose metal atoms and create new organic compounds. A few years later, in 1991, Iijima et al. observed of hollow graphitic tubes or carbon nanotubes by Transmission Electron Microscopy (TEM) which form another member of the fullerene family (Figure 8) [27]. The strength and flexibility of carbon nanotubes make them potentially useful in many nanotechnological applications. Currently, Carbon nanotubes are used as composite fibers in polymers and beton to improve the mechanical, thermal and electrical properties of the bulk product. They also have potential applications as field emitters, energy storage materials, catalysis, and molecular electronic components.
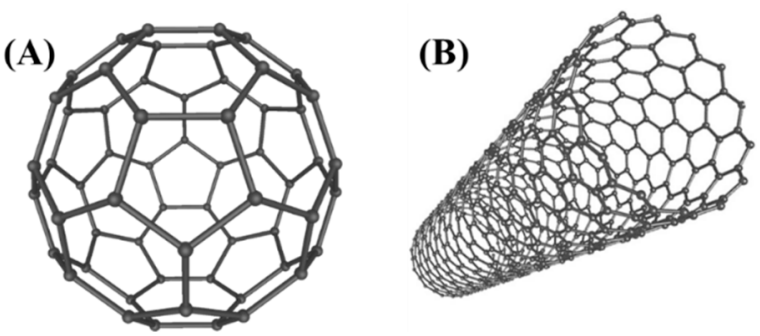

Figure 8. Schematic of a C60 buckyball (Fullerene) (A) and carbon nanotube (B). 
In 2004, a new class of carbon nanomaterials called carbon dots (C-dots) with size below $10 \mathrm{~nm}$ was discovered accidentally by Xu et al. during the purification of single-walled carbon nanotubes [28]. C-dots with interesting properties have gradually become a rising star as a new nanocarbon member due to their benign, abundant and inexpensive nature [29]. Possessing such superior properties as low toxicity and good biocompatibility renders C-dots favorable materials for applications in bioimaging, biosensor and drug delivery [30-35]. Based on their excellent optical and electronic properties, C-dots can also offer exciting opportunities for catalysis, energy conversion, photovoltaic devices and nanoprobes for sensitive ion detection [36-39]. After the discovery of "graphene" in 2004, carbon-based materials became the backbone of almost every field of science and engineering.

In the meantime, nanoscience progressed in other fields of science like in computer science, bio and engineering. Nanoscience and technology progressed in computer science to decrease the size of a normal computer from a room size to highly efficient moveable laptops. Electrical engineers progressed to design the complex electrical circuits down to nanoscale level. Also, many advances are noticed in smart phone technology and other modern electronic devices for daily uses.

At the beginning of 21st century, there was an increased interest in the nanoscience and nanotechnology fields. In the United States, Feynman's concept of manipulation of matter at the atomic level played an important role in shaping national science priorities. During a speech at Caltech on 21 January 2000, President Bill Clinton advocated for the funding of research in the field of nanotechnology. Three years later, President George W. Bush signed into law the 21st century Nanotechnology Research and Development Act. The legislation made nanotechnology research a national priority and created the National Technology Initiative (NNI).

Recently, a number of studies highlighted the huge potential that nanotechnologies play in biomedicine for the diagnosis and therapy of many human diseases [40]. In this regard, bio-nanotechnology is considered by many experts as one of the most intriguing field of application of nanoscience. During recent decades, the applications of nanotechnology in many biology related areas such as diagnosis, drug delivery, and molecular imaging are being intensively researched and offered excellent results. Remarkably, a plethora of medical-related products containing nanomaterials are currently on the market in the USA. Examples of "nanopharmaceuticals" include nanomaterials for drug delivery and regenerative medicine, as well as nanoparticles with antibacterial activities or functional nanostructures used for biomarker detection like nanobiochips, nanoelectrodes, or nanobiosensors [41].

One of the most important applications of nanotechnology to molecular biology has been related to nucleic acids. In 2006, Paul Rothemund developed the "scaffolded DNA origami", by enhancing the complexity and size of self-assembled DNA nanostructures in a "one-pot" reaction [42]. The conceptual foundation for DNA nanotechnology was first laid out by Nadrian Seeman in 1982: "It is possible to generate sequences of oligomeric nucleic acids, which will preferentially associate to form migrationally immobile junctions, rather than linear duplexes, as they usually do" [43]. DNA nanotechnology has already become an interdisciplinary research area, with researchers from physics, chemistry, materials science, computer science, and medicine coming together to find solutions for future challenges in nanotechnology [44-47]. Notably, years of extensive studied made possible to use DNA and other biopolymers directly in array technologies for sensing and diagnostic applications.

Remarkable progresses have been made also in the field of nano-oncology by improving the efficacy of traditional chemotherapy drugs for a plethora of aggressive human cancers [48,49]. These advances have been achieved by targeting the tumour site with several functional molecules including nanoparticles, antibodies and cytotoxic agents. In this context, many studies showed that nanomaterials can be employed itself or to deliver therapeutic molecules to modulate essential biological processes, like autophagy, metabolism or oxidative stress, exerting anticancer activity [50].

Hence, nano-oncology is a very attractive application of nanoscience and allows for the improvement of tumour response rates in addition to a significant reduction of the systemic toxicity associated with current chemotherapy treatments. 
Nanotechnology has been used to improve the environment and to produce more efficient and cost-effective energy, such as generating less pollution during the manufacture of materials, producing solar cells that generate electricity at a competitive cost, cleaning up organic chemicals polluting groundwater, and cleaning volatile organic compounds (VOCs) from air.

However, the application of computational approaches to nanomedicine is yet underdeveloped and is an exigent area of research. The need for computational applications at the nano scale has given rise to the field of nanoinformatics.

Powerful machine-learning algorithms and predictive analytics can considerably facilitate the design of more efficient nanocarriers. Such algorithms provide predictive knowledge on future data, have been mainly applied for predicting cellular uptake, activity, and cytotoxicity of nanoparticles.

Data mining, network analysis, quantitative structure-property relationship (QSPR), quantitative structure-activity relationship (QSAR), and ADMET (absorption, distribution, metabolism, excretion, and toxicity) predictors are some of the other prominent property evaluations being carried out in nanoinformatics.

Nanoinformatics has provided a major supplementary platform for nanoparticle design and analysis to overcome such in vitro barriers. Nanoinformatics exclusively deals with the assembling, sharing, envisaging, modeling, and evaluation of significant nanoscale level data and information. Nanoinformatics also facilitates chemotherapy by improving the nano-modeling of the tumor cells and aids detection of the drug-resistant tumors easily. Hyperthermia-based targeted drug delivery and gene therapy approaches are the latest nanoinformatics techniques proven to treat cancer with least side effects [51].

\section{Conclusions}

The progress of nanoscience and nanotechnology in different fields of science has expanded in different directions, to observe things from micro to nano, to even smaller scale sizes by different microscopes in physics, from micro size bulk matter to small size carbon dots in chemistry, from room size computers to mobile slim size laptops in computer science, and to observe deeply the behavior of the cell's nucleus to study single complicated biomolecules at the nano level in biological science. All these progressions in different fields of science have been generally overviewed and summarized in Figure 9.

In only a few decades, nanotechnology and nanoscience have become of fundamental importance to industrial applications and medical devices, such as diagnostic biosensors, drug delivery systems, and imaging probes. For example, in the food industry, nanomaterials have been exploited to increase drastically the production, packaging, shelf life, and bioavailability of nutrients. In contrast, zinc oxide nanostructures display antimicrobial activity against food-borne bacteria, and a plethora of different nanomaterials are nowadays used for diagnostic purposes as food sensors to detect food quality and safety [52].

Nanomaterials are being used to build a new generation of solar cells, hydrogen fuel cells, and novel hydrogen storage systems capable of delivering clean energy to countries still reliant on traditional, non-renewable contaminating fuels.

However, the most significant advances in nanotechnology fall in the broad field of biomedicine and especially in cancer therapeutics because of their great potential to offer innovative solutions to overcome the limitations deriving by traditional chemotherapy and radiotherapy approaches.

Recent advances made in the fields of physic, chemistry and material sciences have provided a number of nanomaterials with unique properties, which are expected to improve the treatment of many tumors otherwise resistant to current therapies. This will be possible by merit of their intrinsic cytotoxic activity and/or because of their capability to act as nanocarriers to deliver therapeutic molecules, such as drugs, proteins, nucleic acids or immune agents. These innovative biomedical applications are currently exploited in a variety of clinical trials and, in the near future, may support major development in the therapy of cancer. 


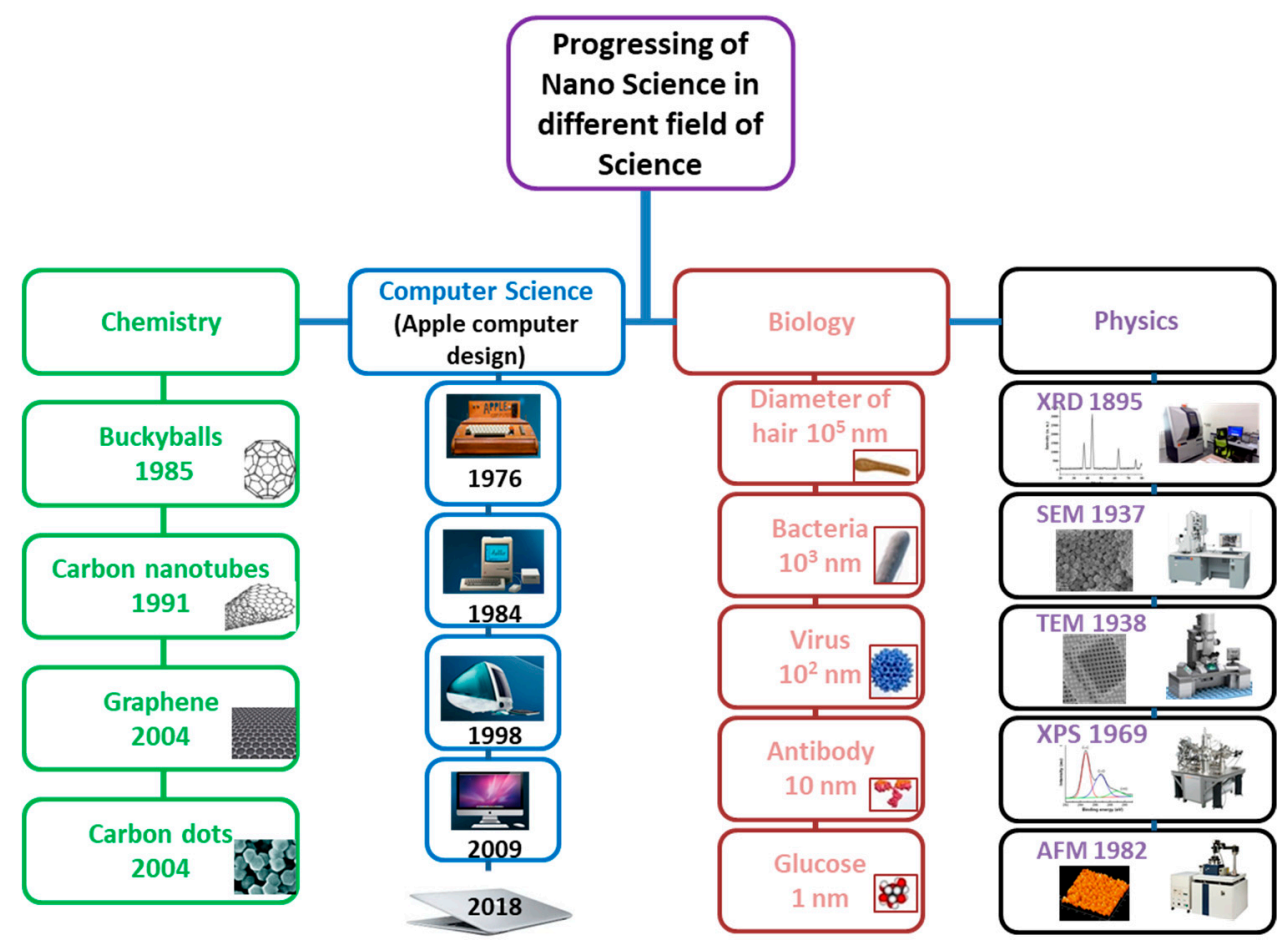

Figure 9. Progress in nanoscience and nanotechnology in different fields of science.

In 2018, the budget for NNI was 1.2 billion dollars (\$) to support nanoscience, engineering and technology. Still, scientists are working for new breakthroughs in nanoscience and nanotechnology in order to make human life easier and more comfortable.

In this context, Table 1 presents the historical development of nanoscience and nanotechnology.

Table 1. Evolution Timeline of Nanoscience and Nanotechnology.

\begin{tabular}{ccc}
\hline Year & Event & References \\
\hline $\begin{array}{c}\text { 4th Century } \\
\text { 500-1450 }\end{array}$ & Lycurgus Cup (Colored glass). & {$[12]$} \\
$1450-1600$ & Cathedrals (Stained glasses windows). & {$[53]$} \\
1857 & Deruta Pottery (Iridescent/metallic clusters). & {$[53]$} \\
1908 & Gustav Mie (Light scattering nanoparticles). & {$[18]$} \\
1928 & Edward Synge (Near-field optical microscope). & {$[54]$} \\
1931 & Max Knoll and Ernst Ruska (invention of transmission electron & {$[55]$} \\
1936 & microscope (TEM)). & {$[56,57]$} \\
1947 & Erwin Müller (Invention of field electron microscope). & {$[58]$} \\
1951 & Erwin Müller (Invention of field-ion microscope, first to see atoms on & {$[60,61]$} \\
1953 & the surface). & {$[62]$} \\
1956 & James Watson and Francis Crick (Discovery of DNA). & {$[63]$} \\
1958 & Arthur Von Hippel (Molecular Engineering). & {$[64]$} \\
1959 & Leo Esaki (Electron tunneling). & {$[5]$} \\
1960 & Richard Feynman (There's Plenty of Room at the Bottom). & {$[65]$} \\
1963 & Charles Plank and Edward Rosinski (Zeolites and catalysis). & {$[66]$} \\
1965 & Stephen Papell (Invention of Ferrofluids). & {$[67]$} \\
1970 & Eiji Osawa (Predicted the existence of C60 in the form of icosahedron). & {$[68]$} \\
1974 & Norio Taniguchi (First use of the term “Nanotechnology"). & {$[6]$} \\
\hline
\end{tabular}


Table 1. Cont.

\begin{tabular}{|c|c|c|}
\hline Year & Event & References \\
\hline 1974 & Mark A. Ratner and Arieh Aviram (Molecular electronics). & [69] \\
\hline 1977 & $\begin{array}{l}\text { Richard P. Van Duyne (Discovery of Surface Enhanced Raman } \\
\text { Spectroscopy (SERS)). }\end{array}$ & [70] \\
\hline 1980 & Jacop Sagiv (Discovery of Self-Assembly Monolayers (SAMs)). & [71] \\
\hline 1981 & $\begin{array}{l}\text { Gerd Binnig and Heinrich Rohrer (Invention of Scanning Tunneling } \\
\text { Microscope (STM)). }\end{array}$ & {$[72]$} \\
\hline 1981 & $\begin{array}{c}\text { Alexey Ekimov (Discovery of nanocrystalline Quantum Dots in a } \\
\text { glass matrix). }\end{array}$ & [73] \\
\hline 1981 & Eric Drexler (Molecular Engineering). & [74] \\
\hline 1982 & $\begin{array}{c}\text { Nadrian Seeman (Development of the concept of DNA } \\
\text { Nanotechnology). }\end{array}$ & {$[43,75]$} \\
\hline 1983 & Louis Brus (Discovery of colloidal Quantum Dots). & {$[76,77]$} \\
\hline 1985 & $\begin{array}{l}\text { Richard Smalley, Robert Curl and Harold Kroto (Discovery of } \\
\text { Buckminsterfullerenes C60). }\end{array}$ & [26] \\
\hline 1986 & $\begin{array}{c}\text { Gerd Binnig, Christoph Gerber and Calvin F. Quate (Invention of } \\
\text { Atomic Force Microscope (AFM). }\end{array}$ & [24] \\
\hline 1987 & $\begin{array}{c}\text { Dimitri Averin and Konstantin Likharev (Single-Electron Tunneling } \\
\text { (SET) transistor). }\end{array}$ & [78] \\
\hline 1990 & $\begin{array}{l}\text { Donald Eigler and Erhard Schweizer (Arranged of individual Xenon } \\
\text { atoms to form the letters IBM). }\end{array}$ & [23] \\
\hline 1991 & Sumio Iijima (Discovery of Multi-wall Carbon nanotubes). & [27] \\
\hline 1992 & Charles T. Kresge (Discovery of mesoporous silica MCM-41). & {$[79,80]$} \\
\hline 1993 & $\begin{array}{c}\text { Sumio Iijima and Donald Bethune (Discovery of Single-wall Carbon } \\
\text { nanotubes). }\end{array}$ & {$[81,82]$} \\
\hline 1996 & Chad Mirkin and Robert Letsinger (SAM of DNA+gold colloids). & [83] \\
\hline 1997 & Zyvex (First nanotechnology company founded). & [84] \\
\hline 1998 & Cees Dekker (Creation of a Transistor using carbon nanotubes). & [85] \\
\hline 1999 & Chad Mirkin (Development of Dip-pen Nanolithography (DPN)). & [86] \\
\hline 2000 & $\begin{array}{c}\text { Mark Hersam and Joseph Lyding (Feedback-Controlled } \\
\text { Lithography (FCL). }\end{array}$ & [87] \\
\hline 2000 & $\begin{array}{c}\text { President Bill Clinton announces US National Nanotechnology } \\
\text { Initiative (NNI). }\end{array}$ & [88] \\
\hline 2001 & $\begin{array}{c}\text { Carlo Montemagno (Molecular nanomachines: molecular motor (rotor) } \\
\text { with nanoscale silicon devices). }\end{array}$ & [89] \\
\hline 2002 & Cees Dekker (Carbon nanotubes functionalized with DNA). & [90] \\
\hline 2003 & $\begin{array}{l}\text { President George W. Bush signed into law the 21st Century } \\
\text { Nanotechnology Research and Development Act. }\end{array}$ & [91] \\
\hline 2003 & Naomi Halas (Development of gold nanoshells). & {$[92,93]$} \\
\hline 2004 & Andre Geim and Konstantin Novoselov (Discovery of graphene). & {$[94]$} \\
\hline 2004 & Xu et al. (Discovery of Fluorescent Carbon dots). & {$[28]$} \\
\hline 2005 & James Tour (Nanocar with turning buckyball wheels). & {$[95,96]$} \\
\hline 2006 & Paul Rothemund (DNA origami). & {$[42]$} \\
\hline 2007 & $\begin{array}{l}\text { J. Fraser Stoddart (artificial molecular machines: pH-triggered } \\
\text { muscle-like). }\end{array}$ & [97] \\
\hline 2008 & $\begin{array}{l}\text { Osamu Shimomura, Martin Chalfie and Roger Y. Tsien (Nobel Prize in } \\
\text { Chemistry for the discovery and development of the green fluorescent } \\
\text { protein, GFP). }\end{array}$ & [98] \\
\hline 2009 & Nadrian Seeman (DNA structures fold into 3D rhombohedral crystals). & [99] \\
\hline 2010 & $\begin{array}{c}\text { IBM (Development of an ultra-fast lithography to create 3D nanoscale } \\
\text { textured surface). }\end{array}$ & [100] \\
\hline 2011 & $\begin{array}{l}\text { Leonhard Grill (scanning tunneling microscope (STM) describes the } \\
\text { electronic and mechanical properties of individual molecules and the } \\
\text { polymer chains). }\end{array}$ & [101] \\
\hline 2016 & $\begin{array}{c}\text { Jean-Pierre Sauvage, Sir J. Fraser Stoddart and Bernard L. Feringa } \\
\text { (Nobel Prize in Chemistry for the design and synthesis of } \\
\text { molecular machines). }\end{array}$ & [102] \\
\hline 2017 & Nobel Prize in Physics 2017: Gravitational waves. & [103] \\
\hline 2018 & World's smallest tic-tac-toe game board made with DNA. & [104] \\
\hline 2018 & Shrinking objects to the nanoscale. & [105] \\
\hline
\end{tabular}


Author Contributions: Conceptualization, S.B. and F.R.; writing-Original draft preparation, S.B.; writing-Review and editing, S.B., M.A., T.T., and M.C.; supervision, F.R. All authors have read and agreed to the published version of the manuscript.

Funding: This research was funded by AIRC IG 2019 (No.23566).

Acknowledgments: Authors are thankful to Fondazione AIRC per la Ricerca sul Cancro for funding.

Conflicts of Interest: The authors declare no conflict of interest.

\section{References}

1. Mansoori, G.; Fauzi Soelaiman, T. Nanotechnology-An Introduction for the Standards Community. J. ASTM Int. 2005, 2, 1-22.

2. Gnach, A.; Lipinski, T.; Bednarkiewicz, A.; Rybka, J.; Capobianco, J.A. Upconverting nanoparticles: Assessing the toxicity. Chem. Soc. Rev. 2015, 44, 1561-1584. [CrossRef] [PubMed]

3. National Nanotechnology Initiative (NNI). Available online: www.nano.gov (accessed on 22 July 2019).

4. Allhoff, F. On the Autonomy and Justification of Nanoethics. Nanoethics 2007, 1, 185-210. [CrossRef]

5. Feynman, R.P. There's plenty of room at the bottom. Eng. Sci. 1960, 23, 22-36.

6. Taniguchi, N.; Arakawa, C.; Kobayashi, T. On the basic concept of nano-technology. In Proceedings of the International Conference on Production Engineering, Tokyo, Japan, 26-29 August 1974.

7. Iqbal, P.; Preece, J.A.; Mendes, P.M. Nanotechnology: The “Top-Down" and “Bottom-Up" Approaches. In Supramolecular Chemistry; John Wiley \& Sons, Ltd.: Chichester, UK, 2012.

8. Drexler, E.K. Engines of Creation: The Coming Era of Nanotechnology; Anchor Press: Garden City, NY, USA, 1986.

9. Drexler, E.K.; Peterson, C.; Pergamit, G. Unbounding the Future: The Nanotechnology Revolution; William Morrow and Company, Inc.: New York, NY, USA, 1991. [CrossRef]

10. The British Museum. Available online: www.britishmuseum.org/research/collection_online/collection_ object_details.aspx?objobjec=61219\&partId=1 (accessed on 22 July 2019).

11. Barber, D.J.; Freestone, I.C. An investigation of the origin of the colour of the Lycurgus Cup by analytical transmission electron microscopy. Archaeometry 1990, 32, 33-45. [CrossRef]

12. Freestone, I.; Meeks, N.; Sax, M.; Higgitt, C. The Lycurgus Cup-A Roman nanotechnology. Gold Bull. 2007, 40, 270-277. [CrossRef]

13. Wagner, F.E.; Haslbeck, S.; Stievano, L.; Calogero, S.; Pankhurst, Q.A.; Martinek, K.-P. Before striking gold in gold-ruby glass. Nature 2000, 407, 691-692. [CrossRef]

14. The New York Times. Available online: www.nytimes.com/imagepages/2005/02/21/science/20050222 NANO1_GRAPHIC.html (accessed on 22 July 2019).

15. Pradell, T.; Climent-Font, A.; Molera, J.; Zucchiatti, A.; Ynsa, M.D.; Roura, P.; Crespo, D. Metallic and nonmetallic shine in luster: An elastic ion backscattering study. J. Appl. Phys. 2007, 101, 103518. [CrossRef]

16. Poole, C.P.; Owens, F.J. Introduction to Nanotechnology; John Wiley \& Sons: New York, NY, USA, 2003.

17. Reibold, M.; Paufler, P.; Levin, A.A.; Kochmann, W.; Pätzke, N.; Meyer, D.C. Materials: Carbon nanotubes in an ancient Damascus sabre. Nature 2006, 444, 286. [CrossRef]

18. Faraday, M. The Bakerian Lecture: Experimental Relations of Gold (and Other Metals) to Light. Philos. Trans. R. Soc. Lond. 1857, 147, 145-181.

19. Binnig, G.; Rohrer, H.; Gerber, C.; Weibel, E. Tunneling through a controllable vacuum gap. Appl. Phys. Lett. 1982, 40, 178. [CrossRef]

20. Binnig, G.; Rohrer, H.; Gerber, C.; Weibel, E. Surface Studies by Scanning Tunneling Microscopy. Phys. Rev. Lett. 1982, 49, 57-61. [CrossRef]

21. Binnig, G.; Rohrer, H.; Gerber, C.; Weibel, E. $7 \times 7$ Reconstruction on Si(111) Resolved in Real Space. Phys. Rev. Lett. 1983, 50, 120-123. [CrossRef]

22. Institute of Physics Polish Academy of Sciences. Available online: http://info.ifpan.edu.pl/ \{\}wawro/ subframes/Surfaces.htm (accessed on 22 July 2019).

23. Eigler, D.M.; Schweizer, E.K. Positioning single atoms with a scanning tunnelling microscope. Nature 1990, 344, 524-526. [CrossRef]

24. Binnig, G.; Quate, C.F.; Gerber, C. Atomic Force Microscope. Phys. Rev. Lett. 1986, 56, 930-933. [CrossRef]

25. Binnig, G. Atomic Force Microscope and Method for Imaging Surfaces with Atomic Resolution. U.S. Patent 4724318A, 16 October 1990. 
26. Kroto, H.W.; Heath, J.R.; O’Brien, S.C.; Curl, R.F.; Smalley, R.E. C60: Buckminsterfullerene. Nature 1985, 318, 162-163. [CrossRef]

27. Iijima, S. Helical microtubules of graphitic carbon. Nature 1991, 354, 56-58. [CrossRef]

28. Xu, X.; Ray, R.; Gu, Y.; Ploehn, H.J.; Gearheart, L.; Raker, K.; Scrivens, W. A Electrophoretic Analysis and Purification of Fluorescent Single-Walled Carbon Nanotube Fragments. J. Am. Chem. Soc. 2004, 126, 12736-12737. [CrossRef]

29. Baker, S.N.; Baker, G.A. Luminescent carbon nanodots: Emergent nanolights. Angew. Chem. Int. Ed. Engl. 2010, 49, 6726-6744. [CrossRef]

30. Esteves da Silva, J.C.G.; Gonçalves, H.M.R. Analytical and bioanalytical applications of carbon dots. TrAC Trends Anal. Chem. 2011, 30, 1327-1336. [CrossRef]

31. Yang, S.-T.; Cao, L.; Luo, P.G.; Lu, F.; Wang, X.; Wang, H.; Meziani, M.J.; Liu, Y.; Qi, G.; Sun, Y.-P. Carbon Dots for Optical Imaging in Vivo. J. Am. Chem. Soc. 2009, 131, 11308-11309. [CrossRef] [PubMed]

32. Yang, S.-T.; Wang, X.; Wang, H.; Lu, F.; Luo, P.G.; Cao, L.; Meziani, M.J.; Liu, J.-H.; Liu, Y.; Chen, M.; et al. Carbon Dots as Nontoxic and High-Performance Fluorescence Imaging Agents. J. Phys. Chem. C 2009, 113, 18110-18114. [CrossRef] [PubMed]

33. Cao, L.; Wang, X.; Meziani, M.J.; Lu, F.; Wang, H.; Luo, P.G.; Lin, Y.; Harruff, B.A.; Veca, L.M.; Murray, D.; et al. Carbon Dots for Multiphoton Bioimaging. J. Am. Chem. Soc. 2007, 129, 11318-11319. [CrossRef] [PubMed]

34. Li, Q.; Ohulchanskyy, T.Y.; Liu, R.; Koynov, K.; Wu, D.; Best, A.; Kumar, R.; Bonoiu, A.; Prasad, P.N. Photoluminescent Carbon Dots as Biocompatible Nanoprobes for Targeting Cancer Cells in Vitro. J. Phys. Chem. C 2010, 114, 12062-12068. [CrossRef]

35. Bayda, S.; Hadla, M.; Palazzolo, S.; Kumar, V.; Caligiuri, I.; Ambrosi, E.; Pontoglio, E.; Agostini, M.; Tuccinardi, T.; Benedetti, A.; et al. Bottom-up synthesis of carbon nanoparticles with higher doxorubicin efficacy. J. Control. Release 2017, 248, 144-152. [CrossRef]

36. Wang, X.; Cao, L.; Lu, F.; Meziani, M.J.; Li, H.; Qi, G.; Zhou, B.; Harruff, B.A.; Kermarrec, F.; Sun, Y.-P. Photoinduced electron transfers with carbon dots. Chem. Commun. 2009, 25, 3774-3776. [CrossRef]

37. Li, Y.; Hu, Y.; Zhao, Y.; Shi, G.; Deng, L.; Hou, Y.; Qu, L. An Electrochemical Avenue to Green-Luminescent Graphene Quantum Dots as Potential Electron-Acceptors for Photovoltaics. Adv. Mater. 2011, 23, 776-780. [CrossRef]

38. Zhou, L.; Lin, Y.; Huang, Z.; Ren, J.; Qu, X. Carbon nanodots as fluorescence probes for rapid, sensitive, and label-free detection of $\mathrm{Hg} 2+$ and biothiols in complex matrices. Chem. Commun. 2012, 48, 1147-1149. [CrossRef]

39. Liu, L.; Li, Y.; Zhan, L.; Liu, Y.; Huang, C. One-step synthesis of fluorescent hydroxyls-coated carbon dots with hydrothermal reaction and its application to optical sensing of metal ions. Sci. China Chem. 2011, 54, 1342-1347. [CrossRef]

40. Kinnear, C.; Moore, T.L.; Rodriguez-Lorenzo, L.; Rothen-Rutishauser, B.; Petri-Fink, A. Form Follows Function: Nanoparticle Shape and Its Implications for Nanomedicine. Chem. Rev. 2017, 117, 11476-11521. [CrossRef]

41. Weissig, V.; Pettinger, T.K.; Murdock, N. Nanopharmaceuticals (part 1): Products on the market. Int. J. Nanomed. 2014, 9, 4357-4373. [CrossRef] [PubMed]

42. Rothemund, P.W.K. Folding DNA to create nanoscale shapes and patterns. Nature 2006, 440, $297-302$. [CrossRef] [PubMed]

43. Seeman, N.C. Nucleic acid junctions and lattices. J. Theor. Biol. 1982, 99, 237-247. [CrossRef]

44. Kumar, V.; Bayda, S.; Hadla, M.; Caligiuri, I.; Russo Spena, C.; Palazzolo, S.; Kempter, S.; Corona, G.; Toffoli, G.; Rizzolio, F. Enhanced Chemotherapeutic Behavior of Open-Caged DNA@Doxorubicin Nanostructures for Cancer Cells. J. Cell. Physiol. 2016, 231, 106-110. [CrossRef]

45. Kumar, V.; Palazzolo, S.; Bayda, S.; Corona, G.; Toffoli, G.; Rizzolio, F. DNA Nanotechnology for Cancer Therapy. Theranostics 2016, 6, 710-725. [CrossRef]

46. Palazzolo, S.; Hadla, M.; Spena, C.R.; Bayda, S.; Kumar, V.; Lo Re, F.; Adeel, M.; Caligiuri, I.; Romano, F.; Corona, G.; et al. Proof-of-Concept Multistage Biomimetic Liposomal DNA Origami Nanosystem for the Remote Loading of Doxorubicin. ACS Med. Chem. Lett. 2019, 10, 517-521. [CrossRef]

47. Palazzolo, S.; Hadla, M.; Russo Spena, C.; Caligiuri, I.; Rotondo, R.; Adeel, M.; Kumar, V.; Corona, G.; Canzonieri, V.; Toffoli, G.; et al. An Effective Multi-Stage Liposomal DNA Origami Nanosystem for In Vivo Cancer Therapy. Cancers 2019, 11, 1997. [CrossRef] 
48. Lee, P.Y.; Wong, K.K.Y. Nanomedicine: A new frontier in cancer therapeutics. Curr. Drug Deliv. 2011, 8 , 245-253.

49. Yuan, Y.; Gu, Z.; Yao, C.; Luo, D.; Yang, D. Nucleic Acid-Based Functional Nanomaterials as Advanced Cancer Therapeutics. Small 2019, 15, 1900172. [CrossRef]

50. Cordani, M.; Somoza, Á. Targeting autophagy using metallic nanoparticles: A promising strategy for cancer treatment. Cell. Mol. Life Sci. 2019, 76, 1215-1242. [CrossRef]

51. Sharma, N.; Sharma, M.; Sajid Jamal, Q.M.; Kamal, M.A.; Akhtar, S. Nanoinformatics and biomolecular nanomodeling: A novel move en route for effective cancer treatment. Environ. Sci. Pollut. Res. Int. 2019, 1-15. [CrossRef] [PubMed]

52. Hulla, J.; Sahu, S.; Hayes, A. Nanotechnology. Hum. Exp. Toxicol. 2015, 34, 1318-1321. [CrossRef] [PubMed]

53. Sciau, P. Nanoparticles in Ancient Materials: The Metallic Lustre Decorations of Medieval Ceramics. In The Delivery of Nanoparticles; InTech: Rijeka, Croatia, 2012. [CrossRef]

54. Mie, G. Beiträge zur Optik trüber Medien, speziell kolloidaler Metallösungen. Ann. Phys. 1908, 330, $377-445$. [CrossRef]

55. Synge, E.H. XXXVIII. A suggested method for extending microscopic resolution into the ultra-microscopic region. Lond. Edinb. Dublin Philos. Mag. J. Sci. 1928, 6, 356-362. [CrossRef]

56. Knoll, M.; Ruska, E. Beitrag zur geometrischen Elektronenoptik. I. Ann. Phys. 1932, 404, 607-640. [CrossRef]

57. Knoll, M.; Ruska, E. Beitrag zur geometrischen Elektronenoptik. II. Ann. Phys. 1932, 404, 641-661. [CrossRef]

58. Müller, E.W. Experimente zur Theorie der Elektronenemission unter dem Einfluß starker Felder. Phys. Z. 1936, 37, 838-841.

59. Shockley, W. Circuit Element Utilizing Semiconductive Material. U.S. Patent 2569347A, 25 September 1951.

60. Müller, E.W. Das Feldionenmikroskop. Z. Phys. 1951, 131, 136-142. [CrossRef]

61. Müller, E.W.; Bahadur, K. Field Ionization of Gases at a Metal Surface and the Resolution of the Field Ion Microscope. Phys. Rev. 1956, 102, 624-631. [CrossRef]

62. Watson, J.D.; Crick, F.H.C. Molecular Structure of Nucleic Acids: A Structure for Deoxyribose Nucleic Acid. Nature 1953, 171, 737-738. [CrossRef]

63. Von Hippel, A. Molecular Engineering. Science 1956, 123, 315-316. [CrossRef] [PubMed]

64. Esaki, L. New Phenomenon in Narrow Germanium p-n Junctions. Phys. Rev. 1958, 109, 603-604. [CrossRef]

65. Plank, C.J.; Rosinski, E.J. Catalytic Cracking of Hydrocarbons with a Crystalline Zeolite Catalyst Composite. U.S. Patent 3140249A, 7 July 1964.

66. Papell, S.S. Low Viscosity Magnetic Fluid Obtained by the Colloidal Suspension of Magnetic Particles. U.S. Patent 3215572A, 2 November 1965.

67. Moore, G.E. Cramming more components onto integrated circuits. Electronics 1965, 38, 114-117. [CrossRef]

68. Osawa, E. Superaromaticity. Kagaku Kyoto 1970, 25, 854-863.

69. Aviram, A.; Ratner, M.A. Molecular rectifiers. Chem. Phys. Lett. 1974, 29, 277-283. [CrossRef]

70. Jeanmaire, D.L.; Van Duyne, R.P. Surface raman spectroelectrochemistry. J. Electroanal. Chem. Interfacial Electrochem. 1977, 84, 1-20. [CrossRef]

71. Sagiv, J. Organized monolayers by adsorption. 1. Formation and structure of oleophobic mixed monolayers on solid surfaces. J. Am. Chem. Soc. 1980, 102, 92-98. [CrossRef]

72. Binnig, G.; Rohrer, H. Scanning Tunneling Microscope. U.S. Patent 4343993A, 10 August 1982.

73. Ekimov, A.; Onushchenko, A. Quantum size effect in the optical-spectra of semiconductor micro-crystals. Sov. Phys. Semicond. 1982, 16, 775-778.

74. Drexler, E.K. Molecular engineering: An approach to the development of general capabilities for molecular manipulation. Proc. Natl. Acad. Sci. USA 1981, 78, 5275-5278. [CrossRef]

75. Pinheiro, A.V.; Han, D.; Shih, W.M.; Yan, H. Challenges and opportunities for structural DNA nanotechnology. Nat. Nanotechnol. 2011, 6, 763-772. [CrossRef]

76. Rossetti, R.; Nakahara, S.; Brus, L.E. Quantum size effects in the redox potentials, resonance Raman spectra, and electronic spectra of CdS crystallites in aqueous solution. J. Chem. Phys. 1983, 79, 1086. [CrossRef]

77. Steigerwald, M.L.; Alivisatos, A.P.; Gibson, J.M.; Harris, T.D.; Kortan, R.; Muller, A.J.; Thayer, A.M.; Duncan, T.M.; Douglass, D.C.; Brus, L.E. Surface derivatization and isolation of semiconductor cluster molecules. J. Am. Chem. Soc. 1988, 110, 3046-3050. [CrossRef]

78. Averin, D.V.; Likharev, K.K. Coulomb blockade of single-electron tunneling, and coherent oscillations in small tunnel junctions. J. Low Temp. Phys. 1986, 62, 345-373. [CrossRef] 
79. Kresge, C.T.; Leonowicz, M.E.; Roth, W.J.; Vartuli, J.C.; Beck, J.S. Ordered mesoporous molecular sieves synthesized by a liquid-crystal template mechanism. Nature 1992, 359, 710-712. [CrossRef]

80. Beck, J.S.; Vartuli, J.C.; Roth, W.J.; Leonowicz, M.E.; Kresge, C.T.; Schmitt, K.D.; Chu, C.T.W.; Olson, D.H.; Sheppard, E.W.; McCullen, S.B.; et al. A new family of mesoporous molecular sieves prepared with liquid crystal templates. J. Am. Chem. Soc. 1992, 114, 10834-10843. [CrossRef]

81. Iijima, S.; Ichihashi, T. Single-shell carbon nanotubes of 1-nm diameter. Nature 1993, 363, 603-605. [CrossRef]

82. Bethune, D.S.; Klang, C.H.; de Vries, M.S.; Gorman, G.; Savoy, R.; Vazquez, J.; Beyers, R. Cobalt-catalysed growth of carbon nanotubes with single-atomic-layer walls. Nature 1993, 363, 605-607. [CrossRef]

83. Mirkin, C.A.; Letsinger, R.L.; Mucic, R.C.; Storhoff, J.J. A DNA-based method for rationally assembling nanoparticles into macroscopic materials. Nature 1996, 382, 607-609. [CrossRef]

84. Zyvex Technologies. Available online: www.zyvex.com (accessed on 22 July 2019).

85. Tans, S.J.; Verschueren, A.R.M.; Dekker, C. Room-temperature transistor based on a single carbon nanotube. Nature 1998, 393, 49-52. [CrossRef]

86. Piner, R.D.; Zhu, J.; Xu, F.; Hong, S.; Mirkin, C.A. “Dip-Pen” Nanolithography. Science 1999, 283, 661-663. [CrossRef]

87. Hersam, M.C.; Guisinger, N.P.; Lyding, J.W. Isolating, imaging, and electrically characterizing individual organic molecules on the $\mathrm{Si}(100)$ surface with the scanning tunneling microscope. J. Vac. Sci. Technol. A Vac. Surf. Films 2000, 18, 1349. [CrossRef]

88. Lok, C. Nanotechnology: Small wonders. Nature 2010, 467, 18-21. [CrossRef] [PubMed]

89. Montemagno, C.D. Nanomachines: A Roadmap for Realizing the Vision. J. Nanoparticle Res. 2001, 3, 1-3. [CrossRef]

90. Williams, K.A.; Veenhuizen, P.T.M.; de la Torre, B.G.; Eritja, R.; Dekker, C. Nanotechnology: Carbon nanotubes with DNA recognition. Nature 2002, 420, 761. [CrossRef] [PubMed]

91. 21st Century Nanotechnology Research and Development Act. Available online: https://www.congress.gov/ bill/108th-congress/senate-bill/189 (accessed on 22 July 2019).

92. Loo, C.; Lin, A.; Hirsch, L.; Lee, M.-H.; Barton, J.; Halas, N.; West, J.; Drezek, R. Nanoshell-Enabled Photonics-Based Imaging and Therapy of Cancer. Technol. Cancer Res. Treat. 2004, 3, 33-40. [CrossRef]

93. Hirsch, L.R.; Stafford, R.J.; Bankson, J.A.; Sershen, S.R.; Rivera, B.; Price, R.E.; Hazle, J.D.; Halas, N.J.; West, J.L. Nanoshell-mediated near-infrared thermal therapy of tumors under magnetic resonance guidance. Proc. Natl. Acad. Sci. USA 2003, 100, 13549-13554. [CrossRef]

94. Novoselov, K.S.; Geim, A.K.; Morozov, S.V.; Jiang, D.; Zhang, Y.; Dubonos, S.V.; Grigorieva, I.V.; Firsov, A.A. Electric Field Effect in Atomically Thin Carbon Films. Science 2004, 306, 666-669. [CrossRef]

95. Shirai, Y.; Osgood, A.J.; Zhao, Y.; Kelly, K.F.; Tour, J.M. Directional Control in Thermally Driven Single-Molecule Nanocars. Nano Lett. 2005, 5, 2330-2334. [CrossRef]

96. Morin, J.-F.; Shirai, Y.; Tour, J.M. En Route to a Motorized Nanocar. Org. Lett. 2006, 8, 1713-1716. [CrossRef]

97. Du, G.; Moulin, E.; Jouault, N.; Buhler, E.; Giuseppone, N. Muscle-like Supramolecular Polymers: Integrated Motion from Thousands of Molecular Machines. Angew. Chem. 2012, 124, 12672-12676. [CrossRef]

98. Sanders, J.K.M.; Jackson, S.E. The discovery and development of the green fluorescent protein, GFP. Chem. Soc. Rev. 2009, 38, 2821. [CrossRef] [PubMed]

99. Zheng, J.; Birktoft, J.J.; Chen, Y.; Wang, T.; Sha, R.; Constantinou, P.E.; Ginell, S.L.; Mao, C.; Seeman, N.C. From molecular to macroscopic via the rational design of a self-assembled 3D DNA crystal. Nature 2009, 461, 74-77. [CrossRef] [PubMed]

100. Knoll, A.W.; Pires, D.; Coulembier, O.; Dubois, P.; Hedrick, J.L.; Frommer, J.; Duerig, U. Probe-Based 3-D Nanolithography Using Self-Amplified Depolymerization Polymers. Adv. Mater. 2010, 22, 3361-3365. [CrossRef] [PubMed]

101. Lafferentz, L.; Ample, F.; Yu, H.; Hecht, S.; Joachim, C.; Grill, L. Conductance of a Single Conjugated Polymer as a Continuous Function of Its Length. Science 2009, 323, 1193-1197. [CrossRef]

102. Richards, V. 2016 Nobel Prize in Chemistry: Molecular machines. Nat. Chem. 2016, 8, 1090. [CrossRef]

103. Nobel Foundation. Nobel Prize in Physics 2017: Gravitational Waves. Available online: www.sciencedaily. com/releases/2017/10/171003095828.htm (accessed on 22 July 2019). 
104. Petersen, P.; Tikhomirov, G.; Qian, L. Information-based autonomous reconfiguration in systems of interacting DNA nanostructures. Nat. Commun. 2018, 9, 5362. [CrossRef]

105. Oran, D.; Rodriques, S.G.; Gao, R.; Asano, S.; Skylar-Scott, M.A.; Chen, F.; Tillberg, P.W.; Marblestone, A.H.; Boyden, E.S. 3D nanofabrication by volumetric deposition and controlled shrinkage of patterned scaffolds. Science 2018, 362, 1281-1285. [CrossRef] 